\title{
DARBĪBAS VĀRDU PAVĒLES IZTEIKSMES DSK. 2. PERSONAS GALOTN̦U LIETOJUMS 17. GS. LATVIEŠU RAKSTU VALODĀ
}

\author{
Jolanta WIŚNIOCH \\ Latvijas Universitātes \\ Baltu valodniecības katedra
}

\section{Ievads}

Latviešu rakstu valodā vairākums pavēles izteiksmes jeb imperatīva formu sakrīt ar īstenības izteiksmes jeb indikatīva tagadnes vai nākotnes formām gan vienskaitlī, gan daudzskaitlī, izņemot dsk. 2. pers. formas, piem., tag. vsk. 2. pers. lasi un imperatīva vsk. 2. pers. lasi!; nāk. dsk. 1. pers. iesim un imperatīva dsk. 1. pers. iesim!, bet tag. dsk. 2. pers. ejat, imperatīva dsk. 2. pers. ejiet! (LVG 2013: 491-492).

Tomēr latviešu valodas izlokšņu vairumā indikatīva tagadnes dsk. 2. pers. forma bieži tiek izmantota arī pamudinājuma izteikšanai. Dsk. 2. pers. $o$-celma verbiem abās izteiksmēs tiek lietota galotne -at (blakus -iet, -ait, -it, -et), $\bar{a}$-celmiem -āt (blakus -ait, -iet), bet $i$-celmiem -it. Galotnes -at, - $\bar{a} t$ un -it reizē apvienoja indikatīva un imperatīva nozìmes, bet galotnes -iet un -ait ieguva imperatīva un indikatīva nozīmi vēlāk (Endzelīns 1951: 888). Pēc Veidemanes domām (2002: 437), tas, ka valodā pastāvēja divas gramatiskās nozīmes un divas atškirīgas formas, varēja izraisìit nepieciešamību tās diferencēt, katrai piesaistot savu nozīmi. Kā raksta Veidemane, šo normēšanas procesu rakstu valodā iesāka Georgs Mancelis un turpināja Ernsts Gliks.

Abu nozīmju un formu noškiriršanas process nav pabeigts arī mūsdienās. Jaunā „Latviešu valodas gramatika“ (LVG 2013: 492), kā arī Paegle (2003: 120-121) min vairākus imperatīva dsk. 2. pers. formu variantus, piem.,

1) galotnes -ait, -aities, kas uzskatītas par novecojušām, poētiskām un tiek dažreiz izmantotas daiḷiteratūrā;

2) indikatīva galotnes -at, -aties sarunvalodā tiek lietotas paralēli ar imperatīva galotnēm -iet, -ieties abu izteiksmju funkcijā. Šāds lietojums literārajā valodā netiek atbalstīts.

Līdz šim veiktie imperatīva formu vēstures pètījumi balstīti galvenokārt uz 17., 18. gs. un vēlāku valodniecisku darbu materiāla, bet mazāk uz reālo lietojumu tā laika tekstos.

Šis raksts sniegs pārskatu par triju lielāko un apjomīgāko 17. gs. rakstu darbu autoru - Georga Manceḷa, Kristofora Fīrekera un Ernsta Glika - izmantotajām pavēles izteiksmes dsk. 2. pers. formām. Pavēles izteiksmes lietoto formu analīze tiks veikta salīdzinājumā ar pētījuma rezultātiem par indikatīva galotnēm tajos pašos avotos (Wiśnioch 2017). 
Abu izteiksmju formu lietojuma analīzes rezultāti rakstu piemineklos kalpos par pamatu mēǵinājumam identificēt veidus un virzienus, kādus izvēlējās katrs no autoriem, veicot pavēles izteiksmes galotņu lietojuma sistematizēšanu un rakstības sakārtošanu.

Šì pētījuma mērķis ir identificēt:

1) kādas imperatīva galotnes izmantotas 17. gs. rakstu avotos;

2) vai un cik lielā mērā imperatīva galotnes sakritušas ar attiecīgajām indikatīva galotnēm;

3) vai imperatīva galotnes izvēli ietekmējis darbības vārda celms;

4) vai ir saskatāma tendence specializēt galotnes konkrētas funkcijas pildīšanai ar vēlmi normēt 17. gs. rakstu valodu.

Pētījumā izmantotas darbības vārdu formas no Glika Jaunās Derības (JD) un portālā www.korpuss.lv/senie pieejamām Vecās Derības grāmatām (VD) ${ }^{1}$ (sk. avotu sarakstu), kā arī no Georga Mancel̦a 1631. g. „Lettifch Vade mecum“ (LVM) un 1654. g. Sprediķu grāmatas pirmās daḷas (LP1).

Tāpat izmantoti Kristofora Fīrekera Bībeles fragmentu tulkojumi, kas ietverti 1685. g. luterāṇu baznīcas rokasgrāmatā „Vermehretes Lettif́ches Handbuch" (VLH).

Veikts materiāla salīdzinājums ar H. Ādolfija gramatiku „Erfter Verluch” (EV), kā arī ar citiem 17 gs. gramatiskajiem darbiem - J. G. Rēhehūzena „Manuductio“ (MLL), t. s. Bihnera gramatikas fragmentiem (A), G. Dreseḷa „Gantz kurtze Anleitung“ (GKA) un J. Langija gramatikas manuskriptu (L).

Visi iepriekšminētie teksti, izņemot gramatikas, ir pieejami portālā www. korpuss.lv/senie, kur materiāls ekscerpēts, ar meklētāja palīdzību atlasot formas ar šādām galotnēm: \%eet/a(ees); \%ait/a resp. \%ajt/a(ees), resp. \%ojt(ees); \%at(ees); \%aht(ees).

Šajā darbā veikts vienīgi indikatīva un imperatīva dsk. 2. pers. lietoto galotņu salīdzinājums. Imperatīva vsk. 2. pers. galotne sakrīt ar attiecīgo ìstenības izteiksmes formu galotni, piem., indikatīva formas ißdohd, darri, effi un imperatīva formas efśi, ghaidi, fteep, leetz, nahtz (LVM).

\section{2. Īstenības un pavēles izteiksmes formas 17. gs. gramatikās}

\subsection{Gramatiku materiāls}

Pirmās ziņas par pavēles izteiksmes formām savā gramatikā ietvēris Rēhehūzens (1644), kurš rakstīja, ka latviešu valodā imperatīva nemaz nav, bet tā vietā lieto indikatīva formas: „Imperativo carent, ideo pro fingulari utuntur pirma perfona præeentis, ut runna/rede du/ pro plurali fecundâ perfonâ plural.

1 Visi Bībeles grāmatu nosaukumi pēc www.lelb.lv/lv_old/box/files/Liturgija/bibeles_gr_ nosaukumi_un_saisinkor.doc 
ejusdẽ præentis, ut, ruñat redet ihr.“ (MLL 19) Darbā nav citu imperatīva formu piemēru, tomēr, ņemot vērā Rēhehūzena uzskatus, par imperatīva formām uzlūkojamas tagadnes 2. pers. formas vienskaitlī un daudzskaitlī, piem., $t u$ luhds, juhß luhdjat (MLL 19) tiešajiem verbiem un tu turräeh $\beta$ / turreh $\beta$, juh $\beta$ turräateh $\beta$ / turrathe $\beta$ (MLL 24) atgriezeniskajiem verbiem. Rēhehūzens dsk. 2. pers. verbu formās lieto vien̄igi galotni -at(ehß) gan tagadnē, gan pagātnē.

Tā saucamajā Bihnera gramatikā (ap 1667-1677) nav aprakstìti teorētiski imperatīva veidošanas principi, bet tā formas redzamas vairāku verbu konjugēšanas paradigmās. Pēc Fennela (1982: 188-192) domām, no materiāla var secināt, ka imperatīva formas sakrìt ar attiecīgajām indikatīva formām. Verbam sargāt tagadnē tiek postulētas divas paradigmas - ìsā un garā. Tas varētu nozīmēt iespēju, ka pastāv divi vsk. 2. pers. formas varianti - śargi un śarga (A 272), tomēr vienskaitlī imperatīvam tiek sniegtas tikai īsās konjugācijas galotnes, bet daudzskaitlī - garās:

$\begin{array}{ll}\text { indikatīvs } & \text { imperatīvs } \\ \text { śargi } & \text { śargi } \\ \text { śarga } & - \\ \text { śargaht } & - \\ \text { śargajaht } & \text { śargajaht / śargajeeta }\end{array}$

Darbā pavēles izteiksmes formas minētas arī verbiem būt, iet un ticēt: Eßi, Eśśeeta (A 268); ei, Eima (A 269); tiz tu, tizet juhs (A 337). Pretstatā Rēhehūzenam Bihnera darbā tiek lietotas divas imperatīva galotnes: -aht, -eeta. Bihners, līdzīgi kā citi 17. gs. gramatiku autori, lieto imperatīva formas ar personas vietniekvārdu pēc pavēles izteiksmes formas. Kā uzskata Fennels (1982: 192), tā varētu būt vācu formu ietekme, jo - kā raksta Endzelīns (1951: 1019) - latviešu valodā imperatīva formām vietniekvārdi tiek pievienoti tikai pretstatā citām personu formām.

Dreseļa un Ādolfija gramatikas, kas abas, pēc pētnieku² domām, balstās uz Fīrekera darbiem, ir atšksirīgas.

Dreseļa gramatikā (1685) nav sniegts imperatīva teorētiskais apraksts, bet no esošajiem piemēriem var secināt, ka vienskaitlī imperatīva formas sakrīt ar attiecīgajām indikatīva formām, kurpretī daudzskaitlī indikatīvā tiek lietota galotne -aht, bet imperatīvā - -ajaht un -aita, kas ir raksturīga $\bar{a}$-celma verbiem. Verbs sargāt konjugēts līdzīgi kā zināt. ${ }^{3}$

2 Bērziñš 1928: 168-170, Arbuzovs 1925: 3-4.

3 Bihners minējis divas atsevišksas grupas verbiem ar galotni -āt nenoteiksmē: a) zināt - zinu un b) runāt-runāju. Gan Bihners, gan Dreselis pie šīs grupas pieskaita verbus ar galotnēm -waht, -weht, -wiht un -woht nenoteiksmē. Dreselis vispirms sadala verbus pēc zilbju skaita vienzilbīgajos un vairākzilbīgajos, pēc tam vairākzilbīgos dala līdzīgi kā Rēhehūzens (Grabis 1955: 123). 
indikatīvs (GKA 16)

tu śarrgi

juhs śarrgaht imperatīvs (GKA 23)

śarrgi tu 'bewahre du'

śargahjaht / śargaita juhs 'bewaret ihr'

Fennels (1984: 245) pamanījis, ka Dreselis saskatīijis saikni starp indikatīva un imperatīva formām vienskaitlī, bet nav attiecinājis to pašu principu uz daudzskaiț̣a formām. Tādējādi viņa darbā indikatīva galotne -aht ir atškỉin̄ga no imperatīva galotnēm -ajaht, -aita. Dreselis indikatīva dsk. 2. pers. tagadnē un pagātnē lieto pārsvarā galotni -aht (attiecīgi 9 un 11 reizes), tai blakus tagadnē 1 reizi parādās arī galotne -at, piem., topat (GKA 61), un 5 reizes galotne -eeta, piem., äsśeeta (GKA 49).

Darbā sniegtajos imperatīva formu piemēros daudzskaitlī bez minētajām -aht, -aita parādās vēl galotne -at, piem., Tohpat juhs (GKA 62), un atgriezeniskais variants -atees, piem., Preezatees juhs (GKA 137). Verba büt imperatīva dsk. 2. pers. formā 1 reizi lietota galotne -eeta: Äsśeeta juhs (GKA 125). Vērā ņemams ir fakts, ka GKA pirmo reizi minēta $\bar{a}$-celma darbības vārdu galotne -ait(a) kā viena no pavēles izteiksmes galotnēm.

Ādolfija gramatikā (1685) imperatīva teorētiskajā aprakstā minēts, ka vsk. 2. pers. indikatīva un imperatīva formas šşiramas, pirmajā gadījumā paturot galotni - $i$, bet otrajā - to atmetot: „Aber die Verba Secundæx und Tertix Conjugationis werffen das i/ welches Secunda Perfona hat in Imperativo gantz weg. Alß/Es d/ennu/ ich jage oder treibe /dfenni/ du jageft oder treibeft. Imperativus. DSenn/ jage oder treibe du. “ (EV 100) Tomēr paša autora noteiktā likumība nav ievērota gramatikā sniegtajos piemēros, kur -i parādās arī pavēles izteiksmes formās, piem., krahji tu (EV 102), l̦auji tu (EV 106).

Citviet Ādolfijs min: „Das Præens Imperativi ift gleich der andern Perfonæ Indicativi Præentis, fo wol in Singulari, als auch in Plurali. Als: Śargi/ hüte du/ śargajt/ śargaht/ śargajeet/ śargajaht/ hütet ihr. Und folches in allen dreyen Conjugationibus." (EV 60) No visām atrodamajām imperatīva dsk. 2. pers. formām visbiežāk - 13 reizes - lietota galotne -at, piem., topat (EV 84). Retāk - tikai 5 reizes -2 . konjugācijas verbiem (vienzilbīgie ar patskani -t priekšā) izmantota galotne -eet, piem., krahjeet (EV 102). Verba dot formās minēti abi imperatīva galotņu varianti: dohdat un dohdeet (EV 131). Refleksīvajiem darbības vārdiem 8 reizes lietota galotne -atees, piem., redfatees (EV 88), bet 1 reizi $-\bar{a}$-celma galotne -ajtees: Śargajtees (EV 78). Galotnes -aht un -ajt, kā potenciālas, parādās tikai gramatikas teorētiskajā dạ̦ā. Pēc Grīsles (1957: 54) domām, pareizi lietota tikai $\bar{a}$-celma galotne -ait, citas - bez noteikta principa.

Langijs savā gramatikā (1685) vienkāršo imperatīva sistēmu daudzskaitlī - vien̄igais no gramatiku autoriem imperatīva nozīmē lieto unificētu galotni -eet, piem., Ähdeet (L 89), dsirdeet (L 101), turreet (L 115). Savukārt 
indikatīvam ir raksturīga galotne -at, piem., eiat (L 79), leekat (L 103), blakus i-celma galotnei -it, piem., mihlit (L 61), essit (L 87).

\subsection{Apkopojums}

No apskatītā gramatiku materiāla par imperatīva dsk. 2. pers. formu lietojumu izriet, ka:

1) Rēhehūzena gramatikā imperatīva formas sakrīt ar attiecīgajām indikatīva formām;

2) Bihners blakus indikatīva galotnei -aht imperatīvā lieto arī galotni -eet;

3) Dreseḷa gramatikā abām izteiksmēm lietoti četri galotņu varianti -aht, -at, -eeta un -ait;

4) Ādolfijs postule četras indikatīva un imperatīva galotnes -ajt, -aht, -at, -eet, tomēr praksē imperatīvā lietotas tikai -at un -eet;

5) Langijs pirmais šķ̧ir indikatīva galotni -at no imperatīva galotnes -eet;

6) atgriezeniskajiem verbiem visi autori lieto galotni -atees. Tikai Ādolfija gramatikā vienu reizi izmantota galotne -ajtees, likumīgi ar $\bar{a}$-celma verba formu.

\section{Pavēles izteiksmes daudzskaitḷa 2. personas galotnes 17. gs. religiskajos rakstos}

\subsection{Tiešo darbības vārdu galotnes}

\subsubsection{G. Manceḷa „Lettifch Vade mecum“ (1631)}

Manceḷa agrīnajā darbā kā galvenās pavēles izteiksmes galotnes izmantotas -eeta un -aita, kas lietotas attiecīgi 181 un 49 reizes, piem., gahdayeeta (2), luhdseeta (4), tohpeeta (5); darraita (10), prohtaita (1), finnaita (4). No visiem apskatītajiem avotiem tikai Manceḷa rokasgrāmatā gan indikatīva, gan imperatīva dsk. 2. pers. galotnēs - eeta un -aita ir saglabāta arhaiskā garākā forma ar gala - $a$ (sal. lietuviešu valodas dsk. 2. pers. galotni -ait(e) - Endzelīns 1951: 692).

Imperatīva nozīmē diviem verbiem lietota arī galotne -aht: dfedaht (1), titzaht (2): ..vnd d Sedaht tam Kungam eekfchan juh/śahms śirdeems (LVM $53,24)$.

Darbības vārda iet pavēles izteiksmes dsk. 2. pers. bez izṇēmuma lietota arhaiskā forma eita (11), sal. liet. eite: eita, un eyta (14). ${ }^{4}$ Darbības vārda būt imperatīva dsk. 2. pers. forma ir efśeeta (16) resp. efśeta (4). Šì pati forma 87 reizes lietota arī indikatìva nozīmē.

4 Plašāk par formas eita izcelsmi sk. Endzelīns 1951: 889. 


\subsubsection{G. Mancel̦a „Lang=gewünfchte Lettifche Poftill“ 1. daḷa (1654)}

Līdzīgi kā LVM, arī sprediķu grāmatā pamudinājuma izteikšanai darbības vārdu dsk. 2. pers. formās izmantotas divas galvenās galotnes: -eeta (307), piem., Jemmeeta / ehdeeta / jemmeeta und d Serreeta wifsí no to Bickeri / to darraita / Zeekahrt /juhß to darreeta mannis peeminnädami (LP1 95, 15), kā arī -aita (57), piem., Ko juhß darraita / to \{tha\} darraita no Śirds (LP1 166, 29). Vienu reizi imperatīva nozīmē lietota arī galotne -aht: Titza ht juhß eekfchan JEfum Chriftum / katters gir patteefśe Deews und Zillwähx (LP1 223, 6).

Forma efśeeta 10 reizes lietota imperatīva, bet 74 - indikatīva nozìmē. 14 reizes izmantota forma eita, tostarp divreiz rakstīts eitha.

\subsubsection{K. Fīrekera „Vermehretes Lettifches Handbuch“ (1685)}

Arī Fīrekers imperatīva dsk. 2. pers. formās galvenokārt lieto galotnes -eet un -ait, attiecīgi 123 un 36 reizes, piem., atmaksajeet (1), behdfeet (1), dohdeet (5); atmakśajt (1), atśakkajt (2), darrajt (9). Tām blakus 13 reizes parādās arī galotne -aht, piem., tohpaht (3), śohdaht (1), śwehtijaht (1).

VLH dati nesaskan ar Ādolfija gramatiku, kas arī sagatavota uz Fīrekera materiālu pamata. Kā minēts, gramatikā imperatīva formās visbiežāk lietota galotne -at (13), retāk - galotne -eet (5), bet galotnes -aht un -ajt, kā potenciālas, minētas tikai gramatikas teorētiskajā dalāā.

VLH darbības vārda būt forma eśśeet resp. effeet 71 gadījumā lietota indikatīiā, bet 28 reizes - imperatīvā. Visos reǵistrētajos gadījumos verba iet imperatīva dsk. 2. pers. forma ir eita (11).

\subsubsection{E. Glika Bībeles tulkojums (1685-1694)}

Kopumā Glika Bībelē atlasītas 2154 pavēles izteiksmes dsk. 2. pers. formas. Arī šeit lielākajai dạ̣ai no tām ir galotne -eet (1479), piem., peeluhkojeet, prezzeet, wehlejeet, un galotne -ait (662), piem., klauśait, darrajt, raudait. VD ojo-celma verbiem 2 reizes parādās arī galotne -ojt: luhkojt, usluhkojt.

Visā Bībelē reǵistrētas arī 14 formas, kurām par pavēles izteiksmes dsk. 2. pers. galotni lietota -at, piem., tizzat (Jn 12:36), turrat (1Tes 5:13), śchkeetat: Mihlee/ ne śch ke e tat śweśchu Leetu eśśam to Karftumu juhśu ftarpâ/ kas jums noteek par Kahrdinaśchanu/ itt kà weena śweścha Leeta pahr jums nahktu (1P 4:12).

Tikai 1 reizi JD tekstā šajā nozīmē izmantota arī galotne -aht: Eijaht un atśluddinajeet Jahñam/ ko juhs eśśaht redfejśchi/ un dfirdejśchi (Lk 7:22).

Bībelē darbības vārda iet imperatīva dsk. 2. pers. formā lietoti divi varianti - eita (93, tostarp 8 JD un 85 VD) un eite (40, pa 20 JD un VD tekstā).

Forma eśśeet arī Glika tulkojumā lietota galvenokārt imperatīvā (41 reizi), piem., Eśśe et mohdrigi un luhdfeet Deewu (Mt, 26:41), bet tā parādās arī indikatīva nozīmē (17). 
Tiešo verbu pavēles izteiksmes dsk. 2. pers. galotnes avotos

\begin{tabular}{|c|c|c|c|c|c|c|c|c|c|c|}
\hline & \multirow{3}{*}{ LVM } & \multirow{3}{*}{ LP1 } & \multicolumn{6}{|c|}{ Bībele } & \multirow{3}{*}{ VLH } & \multirow{3}{*}{ kopā } \\
\hline & & & \multicolumn{5}{|c|}{ JD } & \multirow[b]{2}{*}{ VD } & & \\
\hline & & & $\mathrm{Mt}$ & $\mathrm{Mk}$ & $\mathrm{Lk}$ & Jņ & \begin{tabular}{|l|} 
Citas JD \\
grāmatas
\end{tabular} & & & \\
\hline$-e e t / a$ & 185 & 314 & 85 & 40 & 73 & 39 & 272 & 970 & 123 & 2101 \\
\hline$-a i t / a$ & 49 & 57 & 36 & 22 & 35 & 16 & 84 & 469 & 36 & 804 \\
\hline$-a t$ & - & - & - & - & - & 1 & 6 & 5 & - & 12 \\
\hline$-a h t$ & 2 & 1 & - & - & 1 & - & - & - & 14 & 18 \\
\hline kopā & 236 & 372 & 121 & 62 & 109 & 56 & 363 & 1444 & 173 & 2935 \\
\hline
\end{tabular}

\subsubsection{Apkopojums}

Kopumā apskatītajos 17. gs. avotos atlasītas 2935 pavēles izteiksmes dsk.

2. pers. formas. To lietojuma analīze parāda, ka:

1) visos tekstos kā imperatīva rādìtājs lietota galvenokārt galotne -eet/a (2101). Nedaudz retāk lietota $\bar{a}$-celmiem raksturīgā galotne -ait/a (804);

2) tikai Bībeles tekstā imperatīva nozīmē 12 reizes parādās arī galotne -at;

3) reti - Mancelim 3 gadījumos, Glikam 1 gadījumā, bet Fīrekera darbā 14 reizes - par pavēles izteiksmes galotni kalpo -aht;

4) visu autoru darbos darbības vārda būt forma esiet lietota gan pavēles, gan īstenības izteiksmē. Mancelim un Fīrekeram visbiežāk indikatīva nozīmē, bet Glikam - imperatīvā;

5) visos tekstos vienīgā darbības vārda iet imperatīva dsk. 2. pers. forma ir eita resp. eite.

\subsection{Atgriezenisko darbības vārdu galotnes}

Analizētajos avotos kopumā reg̣istrētas 672 pavēles izteiksmes dsk.

2. pers. galotnes. To analīze parāda, ka:

1) visos avotos visbiežāk (460 gadījumos) lietota galotne -eetees, piem., ne bihfteetees (JD), preezajeetees (JD);

2) tai blakus parādās arī $\bar{a}$-celmiem raksturīga galotne -aitees resp. -ajtees (165 formas), piem., Jkattajtees (VD), darrajtees (JD), turrajtees (VLH), ispirzajtees (VLH);

3) daudz retāk (47 gadījumos, tostarp 24 reizes VLH) reg̣istrēta arī galotne -atees, piem., ne ifśabieftatees (LP1), darbojatees (1Tes 4:11), zellataees (VLH);

4) neviens no autoriem neizmanto potenciāli iespējamo galotni -ahtees, kas mēdz parādīties indikatīva nozīmē. 
Atgriezenisko verbu pavēles izteiksmes dsk. 2. pers. galotnes avotos

\begin{tabular}{|c|c|c|c|c|c|c|c|c|c|c|}
\hline & \multirow{3}{*}{ LVM } & \multirow{3}{*}{ LP1 } & \multicolumn{6}{|c|}{ Bībele } & \multirow{3}{*}{ VLH } & \multirow{3}{*}{ kopā } \\
\hline & & & \multicolumn{5}{|c|}{ JD } & \multirow[b]{2}{*}{ VD } & & \\
\hline & & & Mt & $\mathrm{Mk}$ & $\mathrm{Lk}$ & Jñ & $\begin{array}{l}\text { Citas JD } \\
\text { grāmatas }\end{array}$ & & & \\
\hline -eetees & 28 & 30 & 16 & 5 & 23 & 3 & 68 & 280 & 7 & 460 \\
\hline -aitees & 7 & 38 & 11 & 4 & 7 & - & 13 & 61 & 24 & 165 \\
\hline -atees & 4 & 11 & 1 & - & - & 1 & 2 & 4 & 24 & 47 \\
\hline kopā & 39 & 79 & 28 & 9 & 30 & 4 & 83 & 345 & 55 & 672 \\
\hline
\end{tabular}

\section{4. Īstenības izteiksmes daudzskaitḷa 2. personas galotnes}

\section{7. gs. religisiskajos rakstos}

Iepriekš veiktās pavēles izteiksmes galotņu analīzes rezultāti uzrāda lielas sakritības galotņu -eet(ees) un -ajt(ees) lietojumā 17. gs. autoru reliğiskajos rakstos. Tomēr, ņemot vērā raksta ievadā minēto atzinumu, ka indikatīva un imperatīva galotnes ir savstarpēji cieši saistītas, pētījumā iekḷaujama arī analīze par attiecīgo galotņu lietojumu īstenības izteiksmē. Divu indikatīva formu apskats veikts iepriekšèjā pētījumā par dsk. 2. pers. galotņu -at(ees) resp. -aht(ees) lietojumu 17. gs. rakstu valodas pieminekḷlos (Wiśnioch 2017). Šajā pētījumā noskaidrots, ka reliǵisko tekstu autoriem - Mancelim, Fīrekeram un Glikam - bijusi tendence vienā avotā izvēlēties vienu konkrētu galotnes variantu, kas lietots tagadnē un pagātnē:

1) Manceḷa sprediḳu grāmatā lietota galotne -aht;

2) Fìrekera darbos:

a) gramatikā lietota galotne -aht;

b) Kurzemes rokasgrāmatā lietota galotne -at;

3) Glika Bībeles tulkojumā lietoti abi galotņu varianti.

Šajā rakstā dati (sk. 3. tabulu) papildināti ar informāciju par galotņu -eet(ees), -ajt(ees) lietojumu īstenības izteiksmē, kā arī salīizināti ar LVM darbības vārdu formu materiālu. N̦emot vērā indikatīva tagadnes un imperatīva dsk. 2. pers. kopīgo izcelsmi, tabulās iekḷautas vien̄̄gi attiecīgās tagadnes, bet ne pagātnes formas.

\subsection{G. Mancel̨a „Lettifch Vade mecum“ (1631) un „Lang=gewünfchte Lettifche Poftill“" 1. daḷa (1654)}

Mancel̦a darbos blakus minētajai īstenības izteiksmes galotnei -aht, kas lietota attiecīgi 83 (LVM) un 106 (LP1) gadījumos, nedaudz biežāk parādās arī galotne -eeta, attiecīgi - 129 un 113 reizes, piem., ftaigayeeta (2): MYḷi 
Brahļi / peelukoyeeta nu / ka juhß apdohmige Staigayeeta (LVM 182, 6); warreeta (11): Tha efśeeta nu modrigi allafchien / vnd luhd/eeta ka juhs czeenigi wa r reeta tapt (LVM 27, 13); dfiewojeeta: Ar tahdu Luhkśchanu buhß jums nhe ween to śwähtu Laulibu ee=śahkt / bett arridfan tick illghe / kamähr juhß kohpa dfiewojeeta (LP1 147, 21).

Daudz retāk - 11 reizes - šajā nozīmē lietota arī galotne -aita, piem., ftahwaita (1): Ko ft a hwa it a juhß fcheit wifśu Deenu beß darrbu? (LVM 56, 18); darrait (1): tad buh $\beta$ jums toh $\beta$ Wahrdus Chrifti tha dfirrdeht / ka juh $\beta$ arridfã ta darrait (LP1 539, 31).

Tekstos nav lietotas imperativiva dsk. 2. pers. formas ar galotni -at.

\subsection{K. Fīrekera „Vermehretes Lettifches Handbuch“ un „Erfter Verfuch" (1685)}

Līdzīga situācija vērojama arī Fīrekera tulkojumos Kurzemes rokasgrāmatā. Blakus îstenības izteiksmes galotnei -aht, kas lietota 100 gadījumos, tikpat bieži - 99 reizes - reg̣istrēta arī tagadnes dsk. 2. pers. galotne -eet, piem., eepreezinajeet (1), luhdfeet (3), turreet (4). 28 gadījumos tā izmantota verba būt tagadnes formā eśśeet, piem., Jo winf fch gann finnaja śawu Wiltineeku / tapehz śazzija wiņfch / juhs ne eśśeet wiśśi śchķihfti (VLH 37, 25).

Tikai 4 gadījumos lietota $\bar{a}$-celma galotne -ait: śakkajt (2) un Jkattajt (2), piem., Juhs Wihri no Galilejas / koftahweet juhs / in fkatt a jt us Debbes? (VLH 48, 20).

Arī šajā gadījumā 1685. g. gramatikas teksts ir atškirīịs. EV galvenā indikatīva galotne gan tagadnē, gan pagātnē ir -at, kas lietota attiecīgi 224 un 231 gadījumā. Tikai 4 reizes šajā funkcijā lietota galotne -aht.

\subsection{E. Glika Bībeles tulkojums (1685-1694)}

Glika Bībeles tulkojumā īstenības izteiksmes dsk. 2. pers. funkcijā lietota pārsvarā galotne -at (1539 gadījumos), izņemot Mateja un Marka evaņgeêlijus, kur lielākoties izmantota galotne -aht (kopumā 210 reizes). Lūkas evaņgéelija tekstā abu galotņu skaits ir identisks - 53 -at un 53 -aht.

Pretstatā Mancelim un Fīrekeram Glika darbā galotne -eet indikatīva nozīmē parādās reti. Tā regீistrēta 6 gadījumos JD un 14 - VD grāmatās. 17 (14 VD) no visiem lietojumiem ir verba būt forma eśśeet, piem., Juhs paśchi eśśe et manni Leezineeki (Jņ 3:28). Pārējie 3 ir verbi śuhdseet (Jņ), peenememeet (Rm), meklejeet (Jñ), piem., Tad waizaja winsśch tohs atkal: Pehz ka mekleje et juhs? (Jụ 18:7).

Arī $\bar{a}$-celma galotne -ait tagadnes dsk. 2. pers. formās reǵistrēta tikai 2 gadījumos - pa vienam Mateja un Marka evaņgēelijos: darrait (Mt 5:47), klauśait (Mk 4:24). 
Tiešo verbu īstenības izteiksmes dsk. 2. pers. galotnes avotos

\begin{tabular}{|c|c|c|c|c|c|c|c|c|c|c|}
\hline & \multirow{3}{*}{ LVM } & \multirow{3}{*}{ LP1 } & \multicolumn{6}{|c|}{ Bībele } & \multirow{3}{*}{ VLH } & \multirow{3}{*}{ kopā } \\
\hline & & & \multicolumn{5}{|c|}{ JD } & \multirow[b]{2}{*}{ VD } & & \\
\hline & & & Mt & $\mathrm{Mk}$ & $\mathrm{Lk}$ & Iņ & $\begin{array}{l}\text { Citas JD } \\
\text { grāmatas }\end{array}$ & & & \\
\hline$-e e t / a$ & 129 & 113 & - & - & 1 & 4 & 1 & 14 & 99 & 361 \\
\hline$-a i t / a$ & 7 & 4 & 1 & 1 & - & - & - & - & 4 & 17 \\
\hline$-a t$ & - & - & - & - & 53 & 133 & 524 & 829 & - & 1539 \\
\hline$-a h t$ & 83 & 106 & 138 & 62 & 53 & 3 & - & 4 & 100 & 549 \\
\hline kopā & 219 & 223 & 139 & 63 & 107 & 140 & 525 & 847 & 203 & 2466 \\
\hline
\end{tabular}

\subsection{Atgriezenisko darbības vārdu galotnes}

Reǵiistrētajām 102 atgriezenisko verbu formām visos avotos par galveno īstenības izteiksmes dsk. 2. pers. galotni kalpo -atees. Tā 5 gadījumos parādās Mancel̦a darbos, 4 reizes - Fīrekera darbā un 82 gadījumos - Bībelē, piem., apghrefchatees (LVM), fteidfatees (LVM), maitajateeß (LP1); dfennatees (VLH); pahrwehrśchatees (JD), śmejatees: Waj jums/ kas juhs taggadin śmeja tee s / jo juhs buhśeet nośkummuśchi un raudaśeet (Lk 6:25).

Tai blakus reti izmantota arī galotne -eetees, attiecīgi - 4 reizes Mancel̦a darbos, pa 2 reizēm Fīrekera un Glika darbā, piem., Eß dohmu jums jaunu Baußlu / ka jums śawà Jtarrpà mieḷoteeß buhß / ka eß jums äßmu mielojis / ka juh $\beta$ arridfan weens ohtru mi eloje et eе $\boldsymbol{\beta}$ (LP1 537, 25). Pavisam reti izmantota arī galotne -aitees, tā 1 reizi lietota LVM un 2 reizes - VLH, piem., Juhß Wieri no Galilea / ko ftahweeta juhß / vnd fkat ta it e e s vs Däbbäfśs? (LVM 133, 12).

Nevienā no avotiem neparādās potenciāli iespējamā galotne -ahtees.

4. tabula

Atgriezenisko verbu īstenības izteiksmes dsk. 2. pers. galotnes avotos

\begin{tabular}{|c|c|c|c|c|c|c|c|c|c|c|}
\hline & \multirow{3}{*}{ LVM } & \multirow{3}{*}{ LP1 } & \multicolumn{6}{|c|}{ Bībele } & \multirow{3}{*}{ VLH } & \multirow{3}{*}{ kopā } \\
\hline & & & \multicolumn{5}{|c|}{ JD } & \multirow[b]{2}{*}{ VD } & & \\
\hline & & & Mt & Mk & Lk & Iņ & $\begin{array}{l}\text { Citas JD } \\
\text { grāmatas }\end{array}$ & & & \\
\hline -eetees & 2 & 2 & - & - & - & - & 1 & 1 & 2 & 8 \\
\hline -aitees & 1 & - & - & - & - & - & - & - & 2 & 3 \\
\hline -atees & 4 & 1 & 3 & - & 1 & 4 & 20 & 54 & 4 & 91 \\
\hline kopā & 7 & 3 & 3 & - & 1 & 4 & 21 & 55 & 8 & 102 \\
\hline
\end{tabular}




\subsection{Apkopojums}

N̦emot vērā veikto īstenības izteiksmes un pavēles izteiksmes dsk. 2. pers. galotņu -eeta, -aita, -at un -aht lietojuma salīdzinājumu, var secināt, ka:

1) Mancelis galotni -eeta lieto gan par indikatīva, gan imperatīva rādītāju, attiecīgi 242 un 495 gadījumos;

2) arī Fīrekers rakstībā nešksir abas formas, abās izteiksmēs lietota pārsvarā galotne -eet, attiecīgi 99 un 123 reizes;

3) galotne -ait Mancelim un Fīrekeram kalpo galvenokārt pamudinājuma izteikšanai - Mancelim 106 gadījumos, bet Fīrekeram - 36; indikatīvā tā izmantota attiecīgi 11 un 5 reizes;

4) galotni - aht abi autori izmanto gandrīz vienīgi īstenības izteiksmē-Mancelis 192 reizes, Fīrekers - 100; š̄ forma ḷoti reti lietota kā imperatīva rādītājs, attiecīgi 3 un 14 reizes;

5) Gliks rīkojies atšķirīgi:

- $\quad$ indikatīvā dsk. 2. pers. galotne ir -at resp. -aht gan tagadnē, gan pagātnē. Ļoti reti tās lietotas imperatīva nozīmē, attiecīgi 14 un 1 reizi;

- $\quad$ imperatīvā izmantotas galotnes -eet un -ait, attiecīgi 1479 un 662 gadījumos. Atkāpes - ar indikatīva nozìmi - sastopamas reti, attiecīgi 20 un 2 reizes.

Aprakstīto galotņu lietojuma salīdzinājumu 17. gs. avotos ilustrē 5. tabula.

5. tabula

Indikativva un imperatīva dsk. 2. pers. galotṇu lietojuma salīdzinājums

17. gs. avotos

\begin{tabular}{|c|c|c|c|c|c|c|c|c|c|}
\hline \multicolumn{2}{|c|}{ galotne } & \multicolumn{2}{c|}{$-\boldsymbol{e e t} / \boldsymbol{a}$} & \multicolumn{2}{c|}{$-\boldsymbol{a i t} / \boldsymbol{a}$} & \multicolumn{2}{c|}{$-\boldsymbol{a t}$} & \multicolumn{2}{c|}{-aht } \\
\hline \multicolumn{2}{|c|}{ izteiksme } & ind. & imp. & ind. & imp. & ind. & imp. & ind. & imp. \\
\hline \multirow{4}{*}{$\infty$} & LVM & 129 & 181 & 7 & 49 & 0 & 0 & 83 & 2 \\
\cline { 2 - 11 } & LP1 & 113 & 314 & 4 & 57 & 0 & 0 & 106 & 1 \\
\cline { 2 - 11 } & JD & 6 & 509 & 2 & 193 & 710 & 7 & 256 & 1 \\
\cline { 2 - 11 } & VD & 14 & 970 & 0 & 469 & 829 & 5 & 4 & 0 \\
\cline { 2 - 11 } & VLH & 99 & 123 & 4 & 36 & 0 & 0 & 100 & 14 \\
\hline
\end{tabular}

\section{Pavēles izteiksmes galotņu dalījums 17. gs. avotos pa darbības vārdu celmiem}

Pavisam analizēta 3601 dsk. 2. pers. formu galotne no četriem apskatītajiem avotiem (sk. 6. tabulu). Kopā skatītas gan tiešo, gan atgriezenisko darbības vārdu formas, kas sadalītas pēc pavēles izteiksmes galotnēm -eet, -ait, -aht 
un -at, kā arī atkarībā no darbības vārda tagadnes celma. Tekstos reg̣istrētas 2554 formas ar galotni -eet(ees), otra visbiežāk lietotā galotne ir -ait(ees), kas izmantota 966 gadījumos. Daudz retāk kā imperatìva formu rādìtāis lietotas galotnes -at(ees) un -aht - attiecīgi 62 un 18 gadījumos.

Tabulā ājo-celma darbības vārdu grupā iekḷauti arī verbi ar infinitīvu -ināt, jo tie bez izņēmuma tagadnes dsk. 2. pers. lietoti ar ājo-celma verbu galotnēm pēc paradigmas:

\begin{tabular}{|l|l|l|}
\hline & \multicolumn{1}{|c|}{ vsk. } & \multicolumn{1}{c|}{ dsk. } \\
\hline 1. pers. & -inaju & -inajam \\
\hline 2. pers. & -ini & $\begin{array}{l}\text {-inajat / } \\
\text {-inajaht }\end{array}$ \\
\hline 3. pers. & -ina & -ina \\
\hline
\end{tabular}

Šāda paradigma raksturīga visiem 17. gs. tekstos reg̣istrētajiem verbiem ar -ināt īstenības izteiksmes tagadnē. Arī pavēles izteiksmes dsk. 2. pers. formās lietotas tikai šîs galotnes.

Attiecīgi darbības vārdu ar -ināt formas ar ājo-celma galotnēm parādās LVM tekstā 5 gadījumos tiešajiem verbiem un 1 atgriezeniskajā formā, LP1 tekstā attiecīgi 4 un 1 gadījumā, Bībelē 110 un 14 gadījumos, bet VLH tekstā 1 un 2 reizes, piem., apbähdenayeeta (LVM 1), ißtruhzenayeetees (LVM 1); us=audfenajeeta (LP1 1); apśweizinajeet 2 (JD 25), paśkubbinajeetees (JD 1); spehzinajeetees (VLH 1).

\subsection{Galotnes -eet(ees) lietojums}

Kā minēts iepriekš, visos analizētajos 17. gs. reliğiska satura darbos par galveno imperatīva dsk. 2. pers. galotni kalpo -eet(a), -eetees, kas lietota ar visiem verbiem, neatkarīgi no to celma tagadnē. Šìs galotnes biežuma secībā lietotas kopumā:

- o-celmiem (665 gadijumos), piem., n,emmeet, leezeet, dfenneetees;

- $\quad$ jo-celmiem (627 gadijumos), piem., luhd/eet, eezelleet, atreebjeetees;

- ajjo-celmiem (293 gadijumos), piem., gahdajeet, runnajeet, apdohmajeetees;

- atematiskajiem verbiem (266 gadījumos), piem., dohdeet, eśśeet, pee $=$ ehdeetees;

- $\quad$ ojo-celmiem (225 gadijjumos), piem., luhkojeet, nofchehlojeet, eekahrojeetees;

- $\quad$-celmiem (178 gadījumos), piem., paftahweet, peeminneet, apśehdeetees;

- èjo-celmiem (122 gadījumos), piem., meklejeet, mihlejeetees, fwehrejeet; 
- $\quad$ sto-celmiem (75 gadījumos, tikai Glika Bībeles tekstā), piem., isnihk/teet, aismirfteet, bihfteetees;

- $\quad$ ijo-celmiem (59 gadījumos), piem., śwehtijeet, isśunnijeet, brihnijeetees;

- $\quad \quad \bar{a}$-celmiem (25 gadījumos), piem., śataiśeet, istihreet, dalleetees;

- ujo-celmiem - 5 gadījumos verba dabūt formā dabujeet.

Imperatīva dsk. 2. pers. formas ar galotni -eet(ees) $\bar{a}$-celma verbiem skatītajos relig̣iskajos avotos kopumā reǵistrētas loti nelielā skaitā. Manceḷa darbos tās lietotas 12 reizes, piem., śattaifśeeta (LVM 2), pamahzeeteeß (LVM 1), ghaideeta (LP1 1), klaufśieteeß (LP1 1), Bībelē kopā 11 reizes, piem., śataiśeet (JD 1), istihreet (JD 1), śohleetees (VD 1), bet VLH tekstā - ne reizi.

\subsection{Galotnes -ait(ees) lietojums}

Visos darbos $\bar{a}$-celma verbiem pārsvarā lietota likumīgi sagaidāmā $\bar{a}$ celma galotne -ait(a), -aitees. Mancelim tā reǵistrēta 135 gadījumos, piem., ghrahpftaita (LVM 1), dallaitees (LVM 1); aptauftaita (LP1 1), mahzaiteeß (LP1 30). Bībelē šì galotne lietota kopumā 583 reizes, piem., śakkajt (JD 7), śildajtees (JD 1); śuhtajt (VD 10), śchķiftajtees (VD 3). Fīrekera tekstā tā parādās 32 gadījumos, piem., darrajt (VLH 9), rahdajtees (VLH 1).

Otru grupu pēc galotnes -ait(ees) lietojuma biežuma avotos veido tagadnes $i$-celma darbības vārdi. Tie Manceḷa darbos reǵistrēti 9 reizes, Glika Bībelē -78 reizes un Kurzemes rokasgrāmatā -9 gadījumos, piem., turraita (LVM 2), noturraitees (LVM 1), paturraita (LP1 1); duśśait (JD 1), turrajtees (JD 8), apgraifajt (VD 1), pahrbaudajtees (VD 1); noturrajtees (VLH 1).

Galotne -ait(ees) reti lietota arī ar tagadnes o-celmiem: Mancelim 5 gadījumos, bet Fīrekeram -2 reizes, piem., aughaita (LVM 1), prohtaitee $\beta$ (LP1 1), ispirzajtees (VLH 1). Glika tulkojumā šo formu skaits ir daudz lielāks. Abās JD un VD grāmatās tā reǵistrēta pat 45 reizes, piem., raudajt (JD 7), leekaitees (JD 1), dfeedajt (VD 28).

Tikai Bībelē-ait(ees) 1 reizi reg̣istrēta tagadnes jo-celma verbam: Jums taps atnefts kahds Mafums Uhdens/ un mafgajeet śawas Kahjas/ un peeśle ed jajte es appakśch ścha Kohka (1Moz 18:4).

\subsection{Galotnes -aht lietojums}

Galotne -aht pavēles izteiksmes dsk. 2. pers. formās četros apskatìtajos avotos reg̣istrēta vien 18 gadījumos. Tā lietota bez jebkāda noteikta principa ar dažādu tagadnes celmu verbiem. Manceḷa darbos tā reǵistrēta 4 reizes ar o-, jo- un i-celma verbu formām: dfedaht (LVM 1), titzaht (LVM 2, LP1 1). Bībelē tā lietota 1 reizi atematiskā darbības vārda iet formā eijaht. Visbiežāk 14 gadījumos - šì galotne reǵistrēta Kurzemes rokasgrāmatas tekstā, kur tā 7 reizes parādās ar äjo-celmiem, piem., aizinajaht (1), atmakśajaht (1), 4 reizes 
ar tagadnes o-celmiem, piem., tohpaht (3), un pa 1 reizei $\bar{a}$-, jo- un $\bar{\imath} j o-$ verbu celmiem formās śohdaht (1), śwehtijaht (1), laujaht (1).

\subsection{Galotnes -at(ees) lietojums}

Galotne -at avotos kopumā reg̣istrēta 62 reizes. Tā lietota ar dažādu tagadnes celmu darbības vārdiem - 17 reizes Manceḷa darbos, 20 reizes Glika tulkojumā un 25 reizes Fīrekera perikopju tulkojumā. Galotne -at lielākoties lietota ar atgriezenisko verbu pavēles izteiksmes formām -54 reizes, piem., sto-celma forma ifśabieftatees (LVM), äjo-celma forma apjautateeß (LP1), $\bar{a}$-celma forma mahzatee $\boldsymbol{\beta}$ (LVM), i-celma forma atkahpjatees (VLH), ojjocelma forma femmojatees (VLH).

Tikai Glika Bībeles tulkojuma tekstā galotne -at reǵistrēta arī 12 tiešo verbu formām, tostarp atematisko eśśat (3), o-celma śchkeetat, $i$-celmu (1), ftahwat (2) un $\bar{a}$-celma - finnat (3).

\subsection{Apkopojums}

Analizējot pavēles izteiksmes galotņu lietojumu 17. gs. reliğiskajos avotos, tajos redzamas lielas sakritības, turklāt attiecīgā galotne izvēlēta apzināti atkarībā no darbības vārda tagadnes celma:

1) galotne -eet(ees) lietota visiem darbības vārdiem neatkarīgi no verba celma tagadnē, visbiežāk $o$ - un jo-celma, retāk $\bar{a}$-celma darbības vārdiem;

2) galotne -ait(ees) visbiežāk lietota likumīgi $\bar{a}$-celma, retāk ājo- un $i$-celma verbiem;

3) tikai Glika Bībelē reǵistrēts diezgan liels formu skaits, kur galotne -ait parādās o-celma verbiem;

4) darbības vārdiem ar -ināt imperatīva dsk. 2. pers. formas konjugētas pēc ājo-celmu paradigmas, tādēḷ tekstos kopumā parādās tikai neliels $\bar{a}$-celma formu skaits;

5) galotne -aht lietota visu celmu verbiem, visbiežāk Kurzemes rokasgrāmatas tekstā;

6) galotne -at(ees) izmantota visbiežāk atgriezenisko darbības vārdu formās, tikai Glika Bībelē tā parādās arī tiešo verbu formās.

\section{Secinājumi}

17. gadsimta latviešu rakstu avotu pavēles un īstenības izteiksmes dsk. 2. pers. formu salīdzinājumā gūtie rezultāti apstiprina iepriekš pamanīto Glika tendenci precizēt formu lietojumu un konkretizēt vienu galotni vienas gramatiskās funkcijas pildīšanai. 
$\frac{\frac{0}{3}}{\frac{\pi}{2}}$

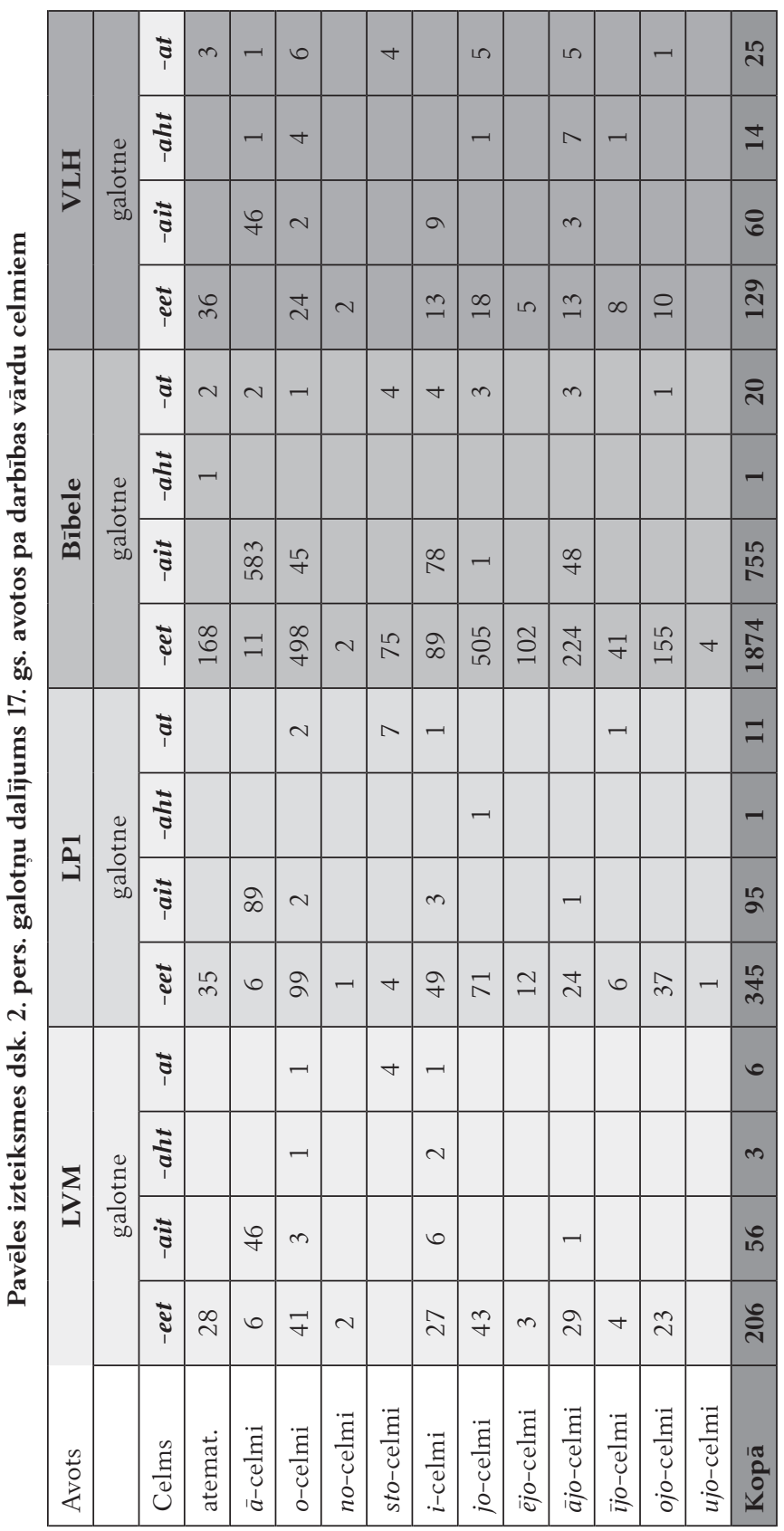


Šāda veida pieeja izmantota Bībeles tulkojumā darbības vārdu īstenības izteiksmes pagātnes 3. pers. galotņu - $a$ un $-e$, kā arī tagadnes un pagātnes dsk. 2. pers. galotñu -at un -aht lietojumā (Wiśnioch 2015; 2017).

Pretstatā šīm formām, kuru lietojums dažādās Bībeles grāmatās atškiriras, pavēles izteiksmes formu ziņā Bībeles teksts uzskatāms par vienu veselumu, jo imperatīva galotnes -eet un -ait visā tekstā lietotas vienveidīgi.

Gliks vienīgais no 17. gs. autoriem noteikti šksir īstenības izteiksmes tagadnes dsk. 2. pers. galotnes no imperatīva galotnēm, lietojot galotnes -at, -aht(ees) pirmajā un -eet, -ait(ees) otrajā funkcijā.

Arī Mancelis un Fīrekers lieto galotni -aht gandrīz vien̄̄gi kā indikatīva rādītāju, tomēr abi autori galotni -eet lieto tikpat bieži imperatīva, cik indikatīva nozìmē.

Visi autori $\bar{a}$-celmiem raksturīgo galotni -ait izmanto likumīgi - ar nedaudziem izṇēmumiem - pamudinājuma izteikšanai. Arī šajā ziņā Gliks ir visprecīzākais, visā Bībelē galotne -ait vien 2 reizes lietota indikatīva funkcijā.

Visiem autoriem kopīgs ir diezgan precīzs dalījums, lietojot galotnes -eet un -ait atkarībā no darbības vārda celma tagadnē. Visos avotos galotne -ait lietota likumīgi galvenokārt tagadnes $\bar{a}$ - un $\bar{a} j o$-celma verbiem, bet galotne -eet - pārējo tagadnes celmu verbiem.

Šajā ziņā Glika darbs atšķiras, jo galotne -ait dažreiz negaidīti parādās arī $o$-celma verbiem.

Visos darbos galotne -at(ees) imperatīva nozīmē izmantota pārsvarā atgriezenisko darbības vārdu formām, tikai Glika Bībelē tā lietota arī tiešo verbu formās.

Neskatoties uz nedaudzajām atkāpēm precizitātes ziņā, Gliks var tikt uzskatīts par pirmo īsteno latviešu valodas rakstības normètāju. Turklāt viņa galvenais princips nav „pareizība“, bet gan vienādas rakstības sistēmas konsekventa ievērošana.

\section{Avoti}

A = Gramatiskie ieraksti mācītāja Bihnera albumā. Citēts no: Fennell, Trevor G. SeventeenthCentury Latvian Grammatical Fragments. Melbourne: Latvian Tertiary Committee, 1982.

$\mathrm{EV}=$ Erfter Verfuch Einer kurtz=verfaffeten Anleitung Zur Lettifchen Sprache .. von Henrico Adolphi .. Mitau .. George Radetzky/ 1685.

GKA = Gantz kurtze Anleitung zur Lettifchen Sprache .. Georgio Drefzell .. Riga Jn Verlegung Georg Matth. Nöllers Jm Jahr Chrifti 1685.

JT = Tas Jauns Teftaments Muhśu Kunga Jefus Kriftus .. Riga .. Johann Georg Wilcken .. M DC $L X X X V$.

$\mathrm{L}=$ Lettifch=Deut/ches Lexicon .. Sampt einer kurtzen Grammatica .. von Johanne Langio .. Citēts no: Fennell, Trevor G. The Grammatical Appendix to Johannes Langius' Latvian-German Lexicon. Melbourne: Latvian Tertiary Committee, 1987. 
LP1 = Lettifche Lang=gewünfchte Poftill .. Durch Georgium Mancelium Semgallum .. Erfter Theil .. Riga .. Gerhard Schröder/ 1654.

$\mathrm{LVM}=$ Lettifch Vade mecum. Handbuch, darinnen folgende Jechs Stücke begriffen: .. Durch GEORGIUM MANCELIUM Semgallum, teutfchen Pa=/torn zu Dörpt bey S. Iohan. Kirchen / und deffelben Kräyfes Probft. Gedruckt zu Riga / durch und in Verlegung Gerhard Schröders. [1631.]

MLL = Manvdvctio Ad Lingvam Lettonicam facilis \& certa, monftrata à Joanne Georgo Rehehusen .. Excufa à Gerhardo Schrödero Typothetâ Rigenfi .. Anno MDCXLIV. Citēts no: Fennell, Trevor G. The First Latvian Grammar: J.G. Rehehusen's „Manuductio ad linguam lettonicam ..": a fac-simile text with annotated translation \& commentary. Melbourne: Latvian Tertiary Committee, 1982.

VD = Ta Śwehta Grahmata Jeb Deewa Śwehtais Wahrds .. Riga .. Johann Georg Wilcken .. M DC LXXXIX.

- Ta Pirma Mohfus Grahmata (1Moz);

- Ta Ohtra Mohfus Grahmata (2Moz);

- Ta Treścha Mohfus Grahmata (3Moz);

- Ta zettorta Mohfus Grahmata (4Moz);

- Ta peekta Mohfus Grahmata (5Moz);

- Ta Jofuus Grahmata (Joz);

- Ta Śohǵu Grahmata (Soğ);

- Ruttes Grahmata (Rut);

- Ta pirma Samuela Grahmata (1Sam);

- Ta ohtra Samuel̦a Grahmata (2Sam);

- Ta pirma Grahmata no teem Ke ehnineem (1Ķēn);

- Ta ohtra Grahmata no teem Ḳehnineem (2K̄ēn).

$\mathrm{VLH}=$ Vermehretes Lettifches Hand $=$ Buch .. außgefertiget von Henrico Adolphi .. Mitau .. George Radetzky/ 1685.

\section{Literatūra}

Arbuzovs, Leonīds. $1925 . \quad$ 17. g. s. Latviešu gramatika bij. Kurzemes hercogu bibliotēkā. Filologu biedrïbas raksti, V, 106-125.

Bērziņš, Ludis. 1928.

Endzelīns, Jānis. 1951.

Kristofors Fīrekers un viņa nozīme latviešu literatūrā. Filologu biedrības raksti, VIII, 145-224.

Fennell, Trevor G. 1982.

Latviešu valodas gramatika. Rīga: Latvijas Valsts izdevniecība.

The first Latvian grammar: J.G. Rehehusen's „Manuductio ad linguam lettonicam ..": a facsimile text with annotated translation \& commentary. Melbourne: Latvian Tertiary Committee.

Fennell, Trevor G. 1984.

Georg Dreszell's Gantz kurtze Anleitung Zur Lettischen Sprache: text, translation, commentary, concordance. Melbourne: Latvian Tertiary Committee.

Fennell, Trevor G. 1987. The grammatical appendix to Johannes Langius' Latvian-German lexicon. Melbourne: Latvian Tertiary Committee.

Grabis, Rūdolfs. 1955.

Pārskats par 17. gadsimta latviešu valodas gramatikām. Valodas un literatūras institūta raksti, V, 205-266.

Grīsle, Rasma. 1958.

17. gadsimta gramatikas kā latviešu valodas vēstures avots. Valodas un literatūras institūta raksti, VII, 245-255. 
$\mathrm{LVG}=$

Paegle, Dzintra. 2003.

Veidemane, Ruta. 2002.

Wiśnioch, Jolanta. 2015.

Wiśnioch, Jolanta. 2017.
Latviešu valodas gramatika. Rīga: LU Latviešu valodas institūts, 2013.

Latviešu literārās valodas morfolog̣ija. Rīga: Zinātne.

Darbības vārds. Aina Blinkena (red.). Latviešu literārās valodas morfoloóiskās sistēmas attīstìba. Lokāmās vārdškiras. Rīga: LU Latviešu valodas institūts, 409-509.

Darbības vārdu pagātnes formu distribūcijas likumi Glika Bībeles tulkojumā. Baltu filoloğija, XXIV (2), 119-141.

Tagadnes un pagātnes dsk. 1. un 2. personas galotņu -am, -at un -ahm, -aht lietojums 17. gs. latviešu valodas rakstos. Baltu filologíia, XXVI (2), 121-136.

Jolanta Wiśnioch

Baltu valodniecības katedra

Latvijas Universitāte

Visvalža iela 4a, Rīga, Latvija

jolawisnioch@gmail.com

\title{
SUMMARY
}

\section{Second Person Plural Endings of Verbs in the Imperative Mood in $17^{\text {th }}$-Century Written Latvian Usage}

\author{
Jolanta WIŚNIOCH
}

The article provides an overview of the second person plural imperative forms used by three of the most outstanding and wide-ranging authors of $17^{\text {th }}$-century Latvian texts, G. Mancelius, Kr. Fürecker and E. Glück. This analysis of the imperative forms is compared with the results of the author's earlier research on the second person plural of the present indicative in the same sources.

These new results confirm Gluck's already observed tendency to delimit more precisely the use of such forms and to bring about the adoption of a single, separate ending for the realisation of a single grammatical function. In the case of the imperative forms, the Bible text can be considered as a single whole, since the imperative endings are used in a consistent manner throughout.

Glück, alone among $17^{\text {th }}$-century writers, definitively separates the second person plural indicative from the corresponding imperative, using -at, -aht(ees) for the former, but -eet, -ait(ees) for the latter.

Mancelius and Fürecker also use the ending -aht almost exclusively as the indicative, but both use -eet just as frequently for the indicative as for the imperative.

All the authors studied share a relatively clear-cut division, using -eet or -ait according to verb type. In all the sources involved, -ait regularly occurs for the most part with $\bar{a}$ - and $\bar{a} j o-$ present stem verbs, while -eet occurs for the other present stem classes.

Throughout our corpus -at(ees) is the predominant imperative ending for reflexive verbs, while in the Glück Bible it is found also with non-reflexives.

In spite of his occasional lapses in precision, Glück can be considered the first real normativist of written Latvian, whose guiding principle is not "correctness", but rather the regular observance of a unified writing system. 